\title{
Peran Pendidikan Agama Islam Terhadap Pengembangan Kualitas Budi Pekerti Siswa Kelas IV SDN Inpres Sorobali
}

Muhammad

STKIP Taman Siswa Bima

muhammadalbab198@yahoo.com

\begin{tabular}{|c|c|}
\hline Artikel Info & Abstrak \\
\hline$\underline{\text { Tanggal Publikasi }}$ & Tujuan melakukan penelitian ini adalah untuk mengetahui bentuk dan \\
\hline 2019-06-30 & tujuan dari pengembangan kualitas budi pekerti siswa, serta mengetahui \\
\hline$\underline{\text { Kata Kunci }}$ & faktor pengambat dalam mengembangankan kualitas budi pekerti siswa di \\
\hline $\begin{array}{l}\text { Pendidikan Agama } \\
\text { Islam }\end{array}$ & $\begin{array}{l}\text { berupa kata-kata tindakan, sumber tertulis, dan foto. adapun metode yang } \\
\text { digunakan adalah metode observasi, wawancara, dan dokumentasi. Hasil }\end{array}$ \\
\hline Budi Pekerti Siswa & $\begin{array}{l}\text { penelitian yang ada di lapangan menunjukan bahwasanya pengembangan } \\
\text { kualitas budi pekerti siswa memiliki perkembangan. Faktor ini dapat dilihat } \\
\text { dari bentuk perilaku siswa yang bersifat sopan dan santun, saling } \\
\text { menghargai, menghormati antara sesama. Hasil wawancara yang dilakukan } \\
\text { di SDN Inpres Sorobali merupakan suatu upaya untuk meningkatkan } \\
\text { perilaku dan sekaligus untuk memperbaiki moral siswa agar dalam diri } \\
\text { mereka terpatri pribadi yang baik. kalaupun masih ada upaya lain yang lebih } \\
\text { baik dari apa yang telah disampaikan peneliti dalam skripsi ini, maka hal itu } \\
\text { dapat dijadikan masukan atau tambahan agar skripsi ini terus berkembang } \\
\text { dan tidak berhenti sampai disini. }\end{array}$ \\
\hline
\end{tabular}

\section{PENDAHULUAN}

Sering terjadinya berbagai peristiwa kekerasan seperti tawuran antar pelajar yang penyebabnya dipicu hanya soal yang tidak terlalu penting tetapi mengakibatkan korban, baik yang luka maupun meninggal. Demikian pula masalah lainya yang menyangkut peserta didik dan masyarakat umum seperti adanya geng motor yaitu kumpulan anak-anak remaja yang mempunyai hobi bermotor yang melakukan tindakan kekerasan, penganiayaan, penjabretan hingga perampokan yang sangat meresahkan masyarakat. kejadian-kejadian tersebut menimbulkan pernyataan bagaimana peran pendidikan dalalm bentuk pola pikir dan tingkah laku atau moral peserta didik maupun masyarakat umum dan bangsa.

Pendidikan tidak dapat dipisahkan dari kehidupan keluarga, sekolah dan masyarakat. Sesuai dengan pendapat Hadirah (2008: 5), bahwa pendidikan sangat berperan penting dalam kehidupan manusia, tanpa pendidikan, manusia tak berdaya. Pada dasarnya pendidikan adalah usaha orang tua atau generasi muda untuk mempersiapkan secara mandiri dan maupun melaksanakan tugas-tugas dalam hidupnya secara baik.

Tujuan pendidikan agama adalah: (1) terbentuknya kepribadian yang utuh jasmani dan rohani (insal kamil) yang tercermin dalam pemikiran maupun tingkah laku terhadap sesama manusia, alam serta Tuhannya, (2) dapat menghasilkan manusia yang tidak hanya berguna bagi dirinya, tapi juga berguna bagi masyarakat dan lingkungan, serta dapat mengambil manfaat yang lebih maksimal terhadap alam semesta untuk kepentingan hidup di dunia dan akherat, (3) merupakan sumber daya pendorong dan pembangkit bagi tingkah laku dan perbuatan yang baik, dan juga merupakan 
pengandali dalam mengarahkan tingkah laku dan perbuatan manusia. Oleh karena itu pembinaan moral harus didukung pengetahuan tentang ke-Islaman pada umumya dan aqidah atau keimanan pada khususnya.

Menurut pandangan Islam, pendidikan harus mengutamakan pendidikan keimanan. Sejarah telah membutikan bahwa pendidikan yang tidak atau kurang memperhatikan pendidikan keimanan akan menghasilkan lulusan yang kurang baik akhlaknya. Akhlak yang rendah itu akan sangat berbahaya bagi kehidupan bersama yang dapat menghancurkan sendi-sendi kehidupan berbangsa dan bernegara. Lulusan sekolah yang kurang kuat imannya akan sangat sulit menghadapi kehidupan zaman yang makin penuh tantangan di masa mendatang.

Oleh karena itu, mengingat pentingnya pendidikan Islam terutama bagi generasi muda, semua elemen bangsa, terutama guru pendidikan Islam, perlu membumikan kembali pendidikan Islam di sekolah-sekolah baik formal maupun informal Suharsimi, (2009: 117).Permasalahannya adalah bagaimana peran pendidikan agama Islam terhadap pengembangan kualitas budi pekerti siswa dapat diterapkan melalui pendidikan agama.

Menurut Arifin Muzayyin (2010: 34) tujuan Pendidikan Keagamaan adalah untuk mempersiapkan peserta didik agar dapat menjalankan peranan yang menuntut penguasaan pengetahuan khusus tentang agama yang bersangkutan. Seiring dengan perkembangan waktu, maka Pendidikan Agama semakin menjadi perhatian dengan pegertian bahwa pendidikan agama semakin dibutuhkan oleh setiap manusia terutama mereka yang masih di bangku sekolah. Dalam Undangundang Sistim Pendidikan Nasional No.20 Tahun 2003 bab I Pasal I ayat 1 menyatakan bahwa pendidikan adalah "usaha sadar dan terencana untuk mewujudkan suasana belajar dan proses pembelajaran agar peserta didik secara aktif mengembangkan potensi dirinya untuk memiliki kekuatan spiritual keagamaan, pengendalian diri, kepribadian, kecerdasan, akhlak mulia serta keterampilan yang diperlukan dirinya, masyarakat, bangsa dan negara. pendidikan merupakan bimbingan secara sadar oleh pendidik terhadap perkembangan jasmani dan rohani siswa menuju terbentuknya kepribadian yang terutama. Ada beberapa unsur yang terdapat dalam pendidikan antara lain yaitu, usaha yang dilakukan secarasadar, ada pendidikan, adayang dididik, mempunyai sadar dan tujuan, dan ada alat-alat yang dipergunakan. Ahmad D. Marimba, (1989: 9).

Setelah penulis uraikan pengertian tentang pendidikan secara umum, penulis akan menguraikan pengertian Pendidikan Agama Islam menurut para ahli. Pendidikan Agama Islam adalah suatu usaha untuk membina dan mengasuh siswa agar senantiasa dapat memahami ajaran Islam secara menyeluruh. Lalu menghayati tujuan, yang pada akhirnya dapat mengamalkan serta menjadikan Islam sebagai pandangan hidup Zakiyah Darajat, (1995: 93). Pendidikan Islam adalah bimbingan yang dilakukan oleh seorang dewasa kepada terdidik dalam masa pertumbuhan agar memiliki kepribadian muslimNur Uhbiyah, (1998: 11). Menurut Ahmad D, Marimba, (1989: 9) kepribadian muslim yaitu kepribadian yang memiliki nilai-nilai Agama Islam, memilih dan memutuskan serta berbuat berdasarkan nilai-nilai Islam, dan tanggung jawab sesuai dengan nilai-nilai Islam. Tujuan artinya suatu yang diharapkan tercapai setelah usaha atau kegiatan selesai Zakiah Darajat, (1996:29). Suatu proses pasti mempunyai tujuan yang hendak dicapai. Begitu juga dalam proses pembelajaran Pendidikan Agama Islam juga mempunyai tujuan yang hendak dicapai

Tujuan Pendidikan Agama Islam tidak bisa terlepas dari tujuan Pendidikan Nasional, karena tujuan Pendidikan Agama Islam merupakan bagian dari tujuan Pendidikan Nasional.Tujuan Pendidikan Nasional adalah tujuan pendidikan yang akan dicapai oleh suatu Negara. Sedangkan tujuan Pendidikan Nasional Indonesia ialah tujuan yang dicapai oleh Bangsa Indonesia yaitu seperti tersebut dalam GBHN yang berbunyi: "Pendidikan Nasional bertujuan meningkatkan kualitas manusia yang beriman dan bertaqwa kepada Tuhan Yang Maha Esa, berbudi pekerti luhur, berkepribadian, mandiri, maju, tangguh, cerdas, profesional, bertanggung jawab, dan produktif serta 
sehat jasmani dan rohani" (UUSPN No. 20 tahun 2003). Tujuan Pendidikan Agama Islam pada dasarnya sejajar dengan tujuan hidup manusia dan peranannya sebagai makhluk ciptaan Allah sebagaimana pendapat Hasan Langgulung bahwa "segala usaha-usaha untuk menjadikan 'abid (Penyembah Allah) inilah tujuan tertinggi Pendidikan Islam" Hasan Langgulung, (1993:57). Aminuddin dkk (2006:36) mendefinisikan tujuan Pendidikan Agama Islam sebagai berikut: "Tujuan Pendidikan Agama Islam yaitu membawa manusia kepada kehidupan yang lebih baik, sejahtera, damai, tentram di dunia dan akherat serta membebaskan manusia dari kehidupan sesat". Menurut Muhammad Abdullah Qodir Ahmad, dalam Zuharini (1983:47) Tujuan Pengajaran Agama Islam adalah sebagai berikut: 1) Membina murid-murid untuk beriman kepada Allah SWT, mencintai, menaati dan berkepribadian yang mulia, karena anak didik yang utama pada tingkat dasar tersebut akan memiliki akhlak yang mulia melalui pengalaman, sikap dan kebiasaan yang membina kepribadian pada masa depan; 2) Memperkenalkan pada hukum-hukum agama dan cara-cara menunaikan ibadah serta membiasakan agama dan mentaat; 3) Mengembangkan pengetahuan agama mereka dan memperkenalkan adab sopan santun serta membi mbing kecerdasan dan kecenderungan mereka dalam mengembangkan pengetahuan sampai mereka terbiasa patuh mengerjakan agama atas dasar cinta dan senang hati; 4) Memantapkan rasa keagamaam pada anak didik, membiasakan diri berakhlak mulia dan membenci pada akhlak yang buruk.

Tujuan pendidikan di indonesia di dalam undang-undang Sistem Pendidikan Nasioanal No 20 tahun 2003, yaitu: "Pendidikan nasioanal bertujuan untuk berkebangnya potensi siswa agar menjadi manusia yangberiman dan bertaqwa pada Tuhan Maha Esa, berakhlak mulia, sehat,berilmu, cakap, kreatif, mandiri, dan menjadi warga negara yang demokratis serta bertanggung jawab. Menurut Ahmad Tafsir, (2007: 89) tujuan Pendidikan Agama Islam itu harus meliputi tiga kawasan daerah (daerah binaan, domain), yaitu kognitif, afektif dan psikomotor. Untuk kawasan kognitif, tujuannya adalah mengembangkan atau membina pemahaman Agama Islam, selain itu kemampuan baca tulis huruf Al-qur'an dan Tarikh Islam agar siswa faham akan ajaran Islam. Pembinaan afektif betujuan agar siswa menerima ajaran Islam. Pembinaan psikomotor bertujuan agar siswa terampil melakukan ajaran Islam dalam kehidupannya sehari-hari. Menurut Aminuddin kk (2006: 38) bahwa ruang lingkup Pendidikan Agama Islam meliputi keserasian, keselarasan, dan keseimbangan antara: a) Hubungan manusia dengan Allah SWT, b) hubungan manusia dengan manusia, c) hubungan manusia dengan sesama dirinya, d) hubungan manusia dengan makhluk lain dan lingkungannya.

Jadi Pendidikan Agama Islam meliputi ruang lingkup hubungan antara manusia dengan tuhanya saja, tetapi meliputi hubungan manusia dengan sesama mahkluk Allah yang lain maupun hubungan manusia tersebut dengan dirinya. Kesemua hubungan tersebut harus seimbang antara hubungan yang satu dengan yang lain, tidak bisa hanya satu ruang saja yang diutamakan.

Istilah Budi pekerti yang pada dasarnya tidak berbeda dengan akhlak adalah kata yang berasal dari bahasa Sansekerta memiliki dengan kedekatan dengan istilah "Tata Krama". Inti ajaran tata krama ini sama dengan inti ajaran Budi Pekerti. Menurut Kamus Besar Bahasa Indonesia, budi pekerti adalah tingkah laku, perangai akhlak ataupun watak. Sikap dan tingkah laku seseorang tercermin dalam kegiatan hidup kesehariannya seperti tampak dalam hubungan dengan Tuhan, hubungan diri sendiri, hubungan dengan keluarga, hubungan dengan masyarakat, ditemukan dalam Al-Qur'an surah Al-Qalam ayat 4. "dan sesungguhnya kamu benar-banar budi pekerti yang agung". (Q.S. Al-Qalam: 4)

Pendapat lain dikemukakan oleh Sjarkawi (2006: 34), bahwa pendidikan budi pekerti adalah proses pendidikan yang ditujukan untuk mengembangkan nilai, sikap, dan perilaku yang memancarkan akhlak mulia atau budi pekerti luhur. Sementara menurut Nurul Zuriah (2011: 38), 
budi pekerti merupakan nilai-nilai hidup manusia yang sungguh-sungguh dilaksanakan bukan karena kebiasaan, tetapi berdasarkan pemahaman dan kesadaran diri untuk menjadi lebih baik.

Pendidikan budi pekerti merupakan program pengajaran di sekolah yang bertujuan mengembangkanwatak atau tabiat siswa dengan cara menghayati nilai-nilai dan keyakinan masyarakat sebagai kekuatan moral dalam hidupnya melalui kejujuran, dapat dipercaya, disiplin, dan kerja sama yang menekankan ranah afektif (perasaan dan sikap) tanpa meninggalkan ranah kognitif (berpikir rasional) dan ranah skill psikomotorik Nurul Zuriah, (2011: 19). Pendapat lain dikemukakan oleh Zubaedi, (2006: 4) bahwa pendidikan budi pekerti merupakan nilai-nilai luhur yang berakar dari agama, adat-istiadat dan budaya bangsa Indonesia dalam rangka mengembangkan kepribadian peserta didik supaya menjadi manusia menjadi baik. Secara umum, ruang lingkup pendidikan budi pekerti adalah penanaman dan pengembangan nilai, sikap dan perilaku peserta didik sesuai nilai-nilai budi pekerti luhur.

Al-Qur'an dan al-Hadist sebagai pedoman hidup umat Islam menjelaskan kriteria baik dan buruknya suatu perbuatan. Al-Qur'an sebagai dasar akhlak menjelaskan tentang kebaikan Rasulullah SAW, sebagai teladan bagi seluruh umat manusia, maka selaku umat Islam sebagai penganut Rasulullah SAW, sebagai teladan bagi umat seluruh manusia, sebagaimana firman Allah Swt, dalam Q.S. 33/Al-Ahzab: 2.

Sesungguhnya telah ada pada (diri) Rasulullah itu suri teladan yang baik bagimu (yaitu) bagi orang yang mengharap (rahmat) Allah dan (kedatangan) hari kiamat dan Dia banyak menyebut Allah. (Q.S. Al-Ahjab: 21).

Berdasarkan ayat diatas dijelaskan bahwasanya terdapat suri tauladan yang baik, yaitu dalam diri Rasulullah SAW yang telah dibekali ahklak yang mulia dan luhur.

Seperti dikatakan Darmodjo anak usia dini adalah anak yang sedang mengalami pertumbuhan baik pertumbuhan intelektual, emosional maupun pertumbuhan badanya, di mana kecepatam pertumbuhan anak pada masing-masing aspek tersebut tidak sama, sehingga terjadi berbagai variasi tingkat pertumbuhan dari ketiga aspek tersebut. Ini suatu faktor yang menimbulkan adanya perbedaan individual pada anak-anak sekolah dasar walaupun mereka dalam usia yang sama. Karakteristik pada anak usia dini antara lain yaitu: a) Senang bermain, Maksudnya dalam usia yang masih dini anak cenderung untuk ingin bermain dan menghabiskan waktunya hanya untuk bermain karena anak masih polos yang dia tahu hanya bermain maka dari itu agar tidak mengalami masa kecil kurang bahagia anak tidak boleh batasi dalam bermain; b) Senang bergerak, Anak senang bergrak maksudnya dalam masa pertumbuhan fisik dan mentalnya anak menjadi hiperaktif lonjak kesana kesini bahkan seperti merasa tidak capek mereka tidak mau diam dan duduk saja c) Senang bekerja dalam kelompok, Anak senang dalam bekerja dalam kelompok maksudnya seorang manusia, anakanak juga mempunyai insting sebagai makhluk sosial yang bersosialisasi dengan orang lain terutama teman sebayanya, terkadang mereka membentuk satu kelompok tertentu untuk bermain; d) Senang diperhatikan, Di dalam satu interaksisosial anak biasanya mencari perhatian teman dengan berbagai cara dilakukan agar orang memperhatikannya e) Senang meniru, Dalam kehidupan sehari-hari anak mencari suatu figur yang sering dia lihat dan dia temui. Mereka kemudian menirukan apa yang dilakukan ingin dia tiru tersebut.

\section{METODE PENELITIAN}

Jenis penelitian yang digunakan dalam penelitian ini adalah penelitian lapangan (field research), sebab data yang dikumpulkan berasal dari tempat penelitian. Penelitian ini bersifat deskriptif kualitatif, yakni prosedur penelitian yang menghasilkan data deskriptif berupa kata-kata yang tertulis dengan tujuan agar dapat mengamati gejala sosial yang dilakukan dalam kehidupan nyata Lexy J. Moleong, (2007: 4). Alasan digunakannya penelitian ini adalah untuk memperoleh pendiskripsian 
mengenai peran Pendidikan Agama Islam terhadap pengembangan kualitas budi pekerti siswa kelas IV SDN Inpres Sorobali.

Yang dimaksud sumber data dalam penelitian adalah data dari mana data dapat diperoleh. Apabila penelitian menggunakan wawancara dalam pengumpulan datanya, maka sumber data disebut responden. Apabila peneliti menggunakan tehnik observasi, maka sumber datanya berupa benda, gerak, atau proses sesuatu. Apabila meneliti menggunakan dokumentasi, maka dokumen atau catatan tersebut yang menjadi sumber data.

Menurut Lofland, yang dikutip oleh Lexi J Moleong, (2007: 6). sumber data penelitian yang utama dalam penelitian kualitatif adalah kata-kata atau tindakan, selebihnya adalah data tambahan, seperti dokumen, dan lain-lain. Berkaitan dengan itu, pada bagian ini, jenis datanya terbagi menjadi kata-kata dan tindakan, sumber data tertulis, dan foto.

Tehnik pengumpulan data adalah cara yang digunakan untuk mengumpulkan informasi atau fakta-fakta di lapangan. Metode-metode pengumpulan data yang digunakan pada penelitian ini adalah:

\section{a. Metode Observasi}

Sugiyono (2013: 135) mengatakan bahwa obervasi merupakan suatu proses yang kompleks, suatu proses yang tersusun dari berbagai proses biologis dan psikologis. Dua diantaranya adalah proses pengamatan dan ingatan. Observasi digunakan untuk menentukan data gejala-gejala siswa yang dapat diamati selama penelitian di dalam pembelajaran. Pengumpulan data ini dilakukan dengan format obsevasi yang telah disusun sebelumnya, observasi dilakukan oleh peneliti. Skala yang digunakan untuk lembar observasi ini adalah skala penilaian. Peneliti akan mencari data mengenai penerapan peran Pendidikan Agama Islam terhadap pengembangan kualitas budi pekerti siswa kelas IV SDN Inpres Sorobali, kepada guru PAI. Observasi dilaksanakan pada saat kegiatan pembelajaran berlangsung, yakni pada saat jadwal pembelajaran PAI di kelas IV. Datadata yang dicari pada tahap ini adalah jalannya proses pembelajaran PAI di kelas IV.

b. Metode Wawancara

Wawancara adalah pengumpulan informasi yang dilakukan dengan cara mengadakan tanya jawab, secara langsung maupun tidak langsung. Tehnik wawancara yang digunakan pada penelitian ini tidak berstruktur, peneliti hanya berpedoman pada garis-garis besar permasalahan yang akan ditanyakan. Dilakukan secara akrab dan luwes dengan beberapa pertanyaan terbuka. Metode ini digunakan untuk memperoleh keterangan yang sesungguhnya, sehingga dapat menggali dan menangkap kejujuran informasi dalam menyampaikan informasi. Wawancara ini di lakukan dengan guru mata pelajaran Pendidikan Agama Islam dan budi pekerti dan siswa kelas IV SDN Inpres Sorobali.

\section{c. Dokumentasi}

Dokumentasi merupakan catatan peristiwa yang sudah berlalu. Dokumen bisa berbentuk tulisan, gambar, atau karya-karya monumental dari seseorang. Telaah dokumen adalah cara pengumpulan informasi yang didapat dari dokumen. Dokumen yang dihimpun dan dianalisis dipilih yang sesuai dengan tujuan dan fokus masalah.

Tehnik sampling merupakan tehnik pengambilan sampel. Untuk menentukan sampel yang akan digunakan dalam penelitian. Penelitian dalam hal ini memakai snowbal sampling. Snowbal sampling adalah tehnik penentuan sampel yang mula-mula jumlahnya kecil kemudian membesar. Ibarat bola salju yang menggelinding yang lama-lama jadi besar. Dalam penentuan sampel pertamatama dipilih satu atau dua orang, tapi karena dengan dua orang ini belum merasa lengkap terhadap data yang diberikan maka penelitian mencari orang lain yang pandang lebih tahu dan dapat 
melengkapi data yang diberikan oleh dua orang sebelumnya. Begitu seterusnya sehingga jumlah sampel semakin banyak. Sugiyono (2011:218).

Teknik analisis data adalah proses pengorganisasian dan mengurutkan data kedalam pola, kategori dan satuan uraian dasar sehingga dapat ditemukan tema dan dirumuskan hipotesis kerja seperti yang direncanakan oleh data. Menurut Miles dan Huberman (1992: 20) teknik analisis data dilakukan dengan beberapa tahapan, diantaranya:

1. Pengumpulan Data

Dilaksanakan dengan cara pencarian data yang diperlukan terhadap bebagai jenis data dan bentuk data yang ada di lapangan, kemudian melaksanakan pencatatan data di lapangan. Dalam penelitian ini peneliti melakukan pencarian berbagai tempat.

2. Penyajian data

Tahap ini merupakan upaya untuk merakit kembali data yang diperoleh dari lapangan selama kegiatan berlangsung. Data yang selama kegiatan diambil dari data yang di sederhanakan dalam reduksi data. Michael Huberman membatasi suatu penyajian sebagai sekumpulan informasi tersusun yang memberi kemungkinan adanya penarikan kesimpulan dan pengambilan tindakan. Penyajian data dilakukan dengan merakit organisasi informasi, deksripsi dalam bentuk narasi yang memungkinkan simpulan penelitian dapat dilakukan denhgan menyusun kalimatsecara logis dan sistematis sehingga mudah dibaca dan dipahami.

3. Reduksi data

Reduksi data adalah proses pemilihan, pemusatan perhatian pada penyederhanaan, pengabstrakan dan transformasi data-data kasar yang muncul dari catatan-catatan tertulis dilapangan (field note). Reduksi data dimulai sejak penelitian mengambil keputusan tentang kerangka kerja konseptual, tentang pemilihan kasus, pertanyaan yang diajukan dan tentang cara pengumpulan data yang dipakai. Reduksi data berlangsung terus menerus selama penelitian kualitatif berlangsung dan merupakan bagian dari analisis. Reduksi data ulang dilakukan sebagai proses seleksi, penyederhanaan dan abstraksi dari catatan lapangan. Proses ini berlangsung sejak awal penelitian maupun pada saat penelitian. Pada saat penelitian reduksi data dilakukan dengan membuat ringkasan dari catatan yang diperoleh dari lapangan dengan membuat cooding, memusatkan tema dan menentukan batas. Reduksi data merupakan bagian dari analisis data yang mempertegas, membuang hal-hal yang tidak penting dan mengatur data sedemikian rupa sehingga kesimpulan penelitian dapat dilakukan.

\section{Penarikan Kesimpulan/Verifikasi}

Penelitian berusaha menarik kesimpulan dan melakukan verifikasi dengan mancari makna setiap gejala yang diperolehnya dari lapangan, mencatat keteranturan dan konfigurasi yang mungkin ada, alur cacualitas dari fenomena dan proporsi. Maka verifikasi dilakukan sepanjang penelitian berlangsung, sehingga menjamin signifikasi atau kebermaknaan hasil penelitian.

\section{HASIL PENELITIAN DAN PEMBAHASAN}

1. Pengembangan budi pekerti siswa SDN Inpres Sorobali

Untuk memperoleh data tentang pengembangan budi pekerti siswa SDN Inpres Sorobali peneliti menggunakan beberapa pendekatan diantaranya mengadakan wawancara dengan Kepala Sekolah, wali kelas, guru mata pelajaran agama Islam, dan siswa. Berdasarkan hasil wawancara peneliti dengan wali kelas memperoleh infomasi bahwa siswa SDN Inpres Sorobali budi pekerti baik, hal itu dapat dilihat dari sikap siswa yang sangat menghormati, menghargai dan menaati guru sebagai pentransfer ilmu pengetahuan dan pemberi keteladanan yang lebih moralitas, menaati tata 
tertib sekolah, kebiasaan siswa mengucapkan salam maupun mencium tangan apabila bertemu dengan guru, melaksanakan yasinan bersama setiap hari jumat. Disamping itu siswa juga saling menghormati, saling menghargai dan tinggi rasa solidaritas sesama teman.

Dari hasil wawancara dengan guru agama mengatakan bahwa siswa SDN Inpres Sorobali berbudi pekerti yang baik karna senakal-nakalnya siswa SDN Inpres Sorobali masih bisa dikendalikan dan ada batas kewajaran. Adapun sistem proses belajar yang dipakai dalam upaya pembinaan budi pekerti siswa menggunakan metode ceramah, guru menunjuk beberapa siswa untuk jadi narasumber dalam diskusi kemudian memberikan kesimpulan dan catatan tentang didkusi, mengenai materi pembelajaran agama yang diberikan disamping teori disertai praktek dengan harapan siswa dapat memprakteknya dalam kehidupan sehari-hari, hal itu cukup efektif karena para siswa dapat mempraktekkannya dalam kehidupan sehari-hari seperti: menghormati dan menghargai guru serta orang yang lebih tua.

Hasil wawancara dengan siswa mengatakan bahwa siswa SDN Inpres Sorobali hampir seluruhnya berbudi pekerti baik, karena guru-gurnya selalu memberikan nasehat serta contoh yang baik terhadap siswa untuk berbuat baik, untuk saling menghargai antara sesama, saling sapa menyapa, dan menghargai kedua orang tua, guru, dan orang yang lebih tua.

Tabel 1. Saat bertemu dengan guru siswa membawa salam, dan mencium tangan gurunya.

\begin{tabular}{ccc}
\hline Pilihan jawaban & Frekuensi & Presentase \\
\hline YA & 7 & $98 \%$ \\
TIDAK & 1 & $2 \%$ \\
JUMLAH & 8 & $100 \%$ \\
\hline
\end{tabular}

Berdasarkan tabel diatas dapat disimpulkan bahwa dalam siswa sebagian sudah berbudi pekerti baik dengan cara membawa salam dan mencium tangan guru. Terbukti dengan jawaban responden yang menyatakan YA sebesar $98 \%$ dan yang menyatakan TIDAK hanya sebesar $2 \%$ saja. Hal ini menunjukan bahwa guru PAI telah mampu mendidik siswa berbudi pekerti baik.

Tabel 2. Guru menjelaskan tentang keuntungan orang yang berbudi pekerti

\begin{tabular}{ccc}
\hline Pilihan jawaban & Frekuensi & Presentase \\
\hline YA & 7 & $98 \%$ \\
TIDAK & 1 & $2 \%$ \\
Jumlah & 8 & $100 \%$ \\
\hline
\end{tabular}

Berdasarkan tabel diatas dapat dismpulkan bahwa dalam menjelaskan tentang keuntungan orang berbudi pekerti baik, guru PAI telah menjelaskan dengan sangat baik. Terbukti dengan jawaban responden yang menyatakan YA sebesar 98\% dan yang menyatakan TIDAK hanya sebesar 2\%. Hal ini telah menunjukan bahwa guru setiap mengajar selalu mengajarkan kepada siswa untuk berbudi pekerti baik.

Tabel 3. Guru selalu menasehati siswa untuk berbuat baik

\begin{tabular}{ccc}
\hline Pilihan jawaban & Frekuensi & Presentase \\
\hline YA & 6 & $97 \%$ \\
TIDAK & 2 & $3 \%$ \\
Jumlah & 8 & $100 \%$ \\
\hline
\end{tabular}

Berdasarkan tabel diatas dapat disimpulkan bahwa guru selalu memberikan nasehat kepada siswa untuk berbudi pekerti baik. Terbukti dengan jawaban responden yang menyataka YA sebesar $97 \%$ dan yang menyatakan TIDAK hanya sebesar 2\%. Hal ini menunjukan bahwa tingkat kepeduliaan guru kepada siswa sudah sangat baik. 
Tabel 4. Ketika pulang kerumah, siswa tidak lupa membawa salam

\begin{tabular}{|c|c|c|}
\hline Pilihan jawaban & Frekuensi & Presentase \\
\hline YA & 6 & $97 \%$ \\
\hline TIDAK & 2 & $3 \%$ \\
\hline Jumlah & 8 & $100 \%$ \\
\hline
\end{tabular}

Berdasarkan tabel diatas dapat disimpulkan bahwa hampir seluruh siswa selalu mengucapkan salam ketika pulan kerumah. Terbukti dengan jawaban responden yang menyatakan YA sebesar 97\% dan yang menyatakan TIDAK sebesar 3\%. Hal inin menunjukan bahwa tingkat kesopanaan sudah mulai tertanam baik dalam diri siswa.

\section{PENUTUP}

Berdasarkan hasil penelitian yang dilakukan dan pembahasan yang telah dipaparkan penulis pada bab sebelumnya, diperoleh kesimpulan sebagai berikut: 1) Upaya guru pendidikan agama Islam dalam meningkatkan budi pekerti siswa di SDN Inpres Sorobali pada umumnya sangat baik. Dalam pendidikan dan pengajaran agama yang diberikan di kelas, tebukti bahwa 98\% guru menjelaskan tentang keuntungan berbudi pekerti, dan 97\% guru selalu menasehati siswa untuk berbuat baik; 2) Budi pekerti siswa di SDN Inpres Sorobali secara keseluruhan sudah baik, terbukti dari beberapa upaya yang dilakukan guru pendidikan agama Islam dalam meningkatkan budi pekerti siswa di SDN Inpres Sorobali telah memperoleh hasil, yaitu saat bertemu dengan guru siswa membawa salam dan mencium tangan guru yaitu 98\% siswa, dan ketika pulang kerumah siswa tidak lupa membawa salam yaitu 97\% siswa.

\section{Daftar Pustaka}

Aminuddin, dkk, 2006.Membangun Karakter dan Kpribadian Melalui Pendidikan Agama Islam. Jakarta: Graha Ilmu.

Muhammad Abdul Qadir, 1983. Metodologi Pengajaran Pendidikan Agama Islam. Jakarta: IAIN. Muzayyin, 2010. Filsafat Pendidikan Islam.Bumi Aksara, Jakarta.

Suharmisi, 2009. Manajemen Penelitian. Jakarta: PT RINEKA CIPTA. Ahmadi, Abu, 2009. Psikologi Sosial. Jakarta: PT Rineka Cipta. Depertemen Pendidikan Nasioanal, 2000.Kamus Besar Bahasa Indonesia. Jakarta: Balai Pustaka.

Jakiyah, 1990.Ilmu Pendidikan Islam. Jakarta: Bumi Aksara.

Warsiah, 2009. Metode Penulisan Karya Ilmiah. Bandung: Laboraturium Pendidikan Kewarganegaraan.

Zuhairini, dkk, 1983.Metode Khusus Pendidikan Agama. Surabaya: Usaha Nasional. Jenny R. F. Kaligis, 1992.Pendidikan IPA II. Jakarta: Dipdikbud, Dirjen Dikti Proyek Pembinaan Tenaga Pendidikan.

Hadirah, 2008. Dasar-dasar pendidikan. UIN Alauddin Makasar.

Dewantara, Pendidikan, 1977. Yogyakarta: Majelis Luhur Persatuan Taman Siswa.

Langgukung, Hasan, 1993. Asas-Asas Pendidikan Islam. Jakarta: Pustaka Al-Husna.

Marimba, 1989.Pengantar Filsafat Pendidikan Islam.Bandung: PT.Alma'rif, Cet,VIII.

Moleong, 2007. Metodologi Penelitian Kualitatif. Bandung: PT. Remaja Roskadarya. Metode Penelitian Kualitatif, 2001. Bandung: Remaja Rosdakarya.

Zuriah, 2011.Pendidikan Moral dan Budi Pekerti Dalam Perspektif Perubahan. Jakarta: Bumi Aksara.

Huberman, 1992. Analisis Data Kualitatif Buku Sumber Tentang Metode-Metode Baru. Jakarta: UIP.

Dahar, 2006.Teori Belajar dan Pembelajaran. Erlangga, Jakarta.

Sjarkawi, 2006. Pembentukan Kepribadian Melalui Peningkatan Moral. Jakarta: Depdiknas. 
Sugiyono, 2011. Metode Penelitian Pendidikan.Bandung: Penerbit Alfabeta.

Sugiyono, 2013.Penelitian Pendidikan (Pendekatan kuantitatif, kualitatif, dan DEDD). Bandung: Alfabeta.

Sudarma, 2014. I Made, Kimia Bahan Alam. Mataram: FMIPA Press. Ahmad, 2007.Metodologi Pengajaran Agama Islam. Bandung: PT Remaja Roskadarya, Cet,IX.

Uhbiyati, 1998.Ilmu Pendidikan Islam. Bandung: CV Pustaka Setia. Undang-Undang SISDIKNIS 2009. (UU RINO. 20 tahun 2003). Jakarta: Sinar Grafik.

Zuhairini dkk, 1983. Metode Khusus Pendidikan Agama. Surabaya: Usaha Nasional.

Zubaedi, 2006.Pendidikan Berbasis Masyarakat, Upaya Untuk Menawarkan Solusi Terhadap Berbagai Problem Sosial. Yogyakarta: Pustaka Pelajar.

Zakiyah, 1995.Pendidikan Islam Dalam Kekeluargaan dan Sekolah. Jakarta: Ruhana.

Zakiyah, 1996.Ilmu Pendidikan Islam. Jakarta: Raneka Cipta.

Zuchdi, 2010.Pendidikan Karakter Dengan Pendekatan Komprehensif: Terintegrasi dalam Perkuliahan dan Pengembangan Kultur Universitas. Yogyakarta: UNY Press. 